\title{
Low Salinity Decreases the Tolerance to Two Pesticides, Beta-cypermethrin and Acephate, of White-leg Shrimp, Litopenaeus vannamei
}

Xiaodan Wang, Erchao Li*, Zequan Xiong, Ke Chen, Na Yu, Zhenyu Du and Liqiao Chen*

School of Life Sciences, East China Normal University, 200241, Shanghai, China

\begin{abstract}
Acute toxic effects of two commonly used pesticides, beta-cypermethrin and Acephate, to the white-leg shrimp, Litopenaeus vannamei, were tested at ambient salinity $5.0 \%$ and $20.0 \%$, by using a static renewal method. The results showed that the mean $\mathrm{LC}_{50}$ values of beta-cypermethrin at 24, 48, 72 and $96 \mathrm{~h}$ were $0.437,0.317,0.203$, and $0.170 \mu \mathrm{g} / \mathrm{L}$ to the white shrimp at $5.0 \%$, and were $0.767,0.440,0.383$, and $0.383 \mu \mathrm{g} / \mathrm{L}$ at $20.0 \%$. The mean $\mathrm{LC}_{50}$ values of Acephate at $24,48,72$, and $96 \mathrm{~h}$ were $51.250,38.007,27.783,18.247 \mathrm{mg} / \mathrm{L}$ at $5.0 \%$, and were 59.853 , $43.490,34.220,27.337 \mathrm{mg} / \mathrm{L}$ at $20.0 \%$. L. vannamei is more sensitive to ambient beta-cypermethrin and Acephate toxicity at salinity $5.0 \%$ than at salinity $20.0 \%$. Beta-cypermethrin is highly toxic to $L$. vannamei at either salinity, while acephate has low toxicity to $L$. vannamei.
\end{abstract}

Keywords: Litopenaeus vannamei; Beta-cypermethrin; Acephate, Toxicity; Salinity

\section{Introduction}

With the rapid development of green revolution in agriculture, pesticides are widely used in pest control. However, it could lead to high concentrations of these pesticides in surface water especially in intensive agricultural areas [1], which are hazards for aquatic species [2]. Most insecticides used in agriculture are organophosphate, Carbamate and synthetic Pyrethroid compounds [3] because of their relatively non-persistent characteristics in the environment. Though these pesticides can rapidly degrade in natural environment, their high acute toxicity to some non-target species has been demonstrated in many laboratory tests [4-7].

Beta-cypermethrin and Acephate are two commonly used pesticides worldwide. Beta-cypermethrin is a synthetic analog of Pyrethrins, extracts from the ornamental Chrysanthemum Cinerariaefolium, and widely used in field pest control [8]. Due to the Lipophilicity, Pyrethroids have a high rate of gill absorption. So they have been reported to be extremely toxic to fish [8-12], but information in crustacean species is still limited. Acephate is a water soluble foliar spray insecticide of moderate persistence and is used on fruit and vegetable crops grown across the world [13]. A number of studies have been conducted on the toxicity of Acephate on different organisms and indicated as a potent Neurotoxicant [14]. It is also found to be mutagenic [15], carcinogenic [16], and Cytotoxic [17]. However, this compound is considered relatively non-toxic to fish with a median lethal concentration $\left(\mathrm{LC}_{50}\right)$

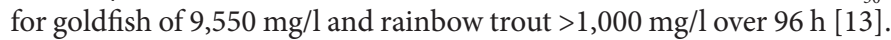
But potential hazard to aquatic crustaceans has been speculated for the heavy use of these compounds and deficiency in the immune system, since lower $\mathrm{LC}_{50}$ values have been found in Americanmysis bahia, Homarus americanus, Penaeus aztecus and P. duprarum [18-19].

The white-leg shrimp, Litopenaeus vannamei, is a typical tropical crustacean that can adapt to a wide range of salinities ranging from 1 to $50.0 \%$ [20], and with the development of inland saline water farming, it has become one of the most popular shrimp for aquaculture in the Central and South American countries [21-22], Thailand [23] and China [24]. Toxicology of ambient pesticides on this species mainly focused on diazinon [25], Propiconazole [25], parathion [26], pyrazosulfuron-ethyl [27], permethrin [27], chlordane [28], DDT [28], lorsban [28] and lindane [28], while there is no report on the toxicology of beta-cypermethrin and Acephate to this species at either salinity, though environment characteristics may affect the toxicity of toxicants to aquatic organisms [29].

This study determined the lethal concentration values of betacypermethrin and Acephate to L. vannamei at two salinities $(5.0 \%$ and $20.0 \%$ ), and found that low salinity decreased the tolerance to these two pesticides in L. vannamei.

\section{Materials and Methods}

L. vannamei were obtained from a farm with pond salinity of $20.0 \%$ in Haikou, Hainan, China. Shrimps were cultured in fiberglass tanks $(60 \times 50 \times 50 \mathrm{~cm})$ at a salinity of $20.0 \%$ for 1 week, then divided randomly into two groups and acclimated to the target salinities $(5.0 \%$ and $20.0 \%$ ) by changing $2.0 \%$ per day. After reaching the targeted salinities, each group was acclimated an additional week. Individual shrimp, weighing $4.54 \pm 0.33 \mathrm{~g}$, were selected for the toxicology experiments. During the pre-culture and acclimation period, shrimps were fed with a commercial feed containing $41.1 \%$ crude protein, $9.6 \%$ crude lipid, $12.0 \%$ ash, and $10.0 \%$ moisture. Seawater was pumped from the Xiuying Coast in Haikou City, and filtered through an activated carbon cartridge for at least 3 days before entering the culture system. The tap water was aerated before being added to the tank to adjust the salinity levels. The water quality parameters during the experiment were $27.7-29.2^{\circ} \mathrm{C}$ for temperature, $5.58-6.79 \mathrm{mg} / \mathrm{L}$ or dissolved oxygen, $8.3 \pm 0.2$ for $\mathrm{pH}$ value and $<0.01 \mathrm{mg} / \mathrm{L}$ for total ammonia-nitrogen.

Beta-cypermethrin and Acephate (Yujing Bio-Tech Co. Ltd., Beijing City, China) stock solutions were prepared at the day of trial starting. As beta-cypermethrin was only slightly dissolved in water, it was prepared

*Corresponding authors: Erchao Li, School of Life Sciences, East China Normal University, 200241, Shanghai, China, Tel: +86-21-54341002; E-mail: ecli@bio.ecnu.edu.cn

Liqiao Chen, School of Life Sciences, East China Normal University, 200241 Shanghai, China, Tel: +86-21-54341002; E-mail: Iqchen@bio.ecnu.edu.cn

Received May 31, 2013; Accepted July 24, 2013; Published July 26, 2013

Citation: Wang X, Li E, Xiong Z, Chen K, Yu N (2013) Low Salinity Decreases the Tolerance to Two Pesticides, Beta-cypermethrin and Acephate, of Whiteleg Shrimp, Litopenaeus vannamei. J Aquac Res Development 4: 190 doi:10.4172/2155-9546.1000190

Copyright: (c) 2013 Wang X, et al. This is an open-access article distributed under the terms of the Creative Commons Attribution License, which permits unrestricted use, distribution, and reproduction in any medium, provided the original author and source are credited. 
Citation: Wang X, Li E, Xiong Z, Chen K, Yu N (2013) Low Salinity Decreases the Tolerance to Two Pesticides, Beta-cypermethrin and Acephate, of White-leg Shrimp, Litopenaeus vannamei. J Aquac Res Development 4: 190 doi:10.4172/2155-9546.1000190

Page 2 of 5

by diluting it in acetone to give the stock material. The control group received a same acetone volume used in the dilution of the dosing concentrations. For both pesticides, six concentrations with a control were used with triplicates for each treatment. The beta-cypermethrin stock solution was diluted to the following concentrations: 0 (control), $0.05,0.1,0.2,0.4,0.8,1.6 \mu \mathrm{g} / \mathrm{L}$ at $5.0 \%$, and 0 (control), $0.1,0.2,0.4,0.8$ $1.6,3.2 \mu \mathrm{g} / \mathrm{L}$ at $20.0 \%$. And the Acephate stock solution was diluted to the following concentrations: 0 (control), 13.3, 20, 30, 45, 67.5, 101.25 $\mathrm{mg} / \mathrm{L}$ at $5.0 \%$, and 0 (control), 20, 30, 45, 67.5, 101.25, $151.88 \mathrm{mg} / \mathrm{L}$ at $20.0 \%$. Ten shrimp were randomly assigned to each treatment and all the tanks were aerated continuously to keep oxygen at adequate levels. Test solutions were renewed totally every $24 \mathrm{~h}$. The experiment was conducted for $96 \mathrm{~h}$ and no feed was supplied to the shrimps during the test period. Observations on mortality and abnormal behavior of the shrimps were conducted at least two times each day. Death was assumed when juvenile white shrimps were non-motile and showed no response when touched with a glass rod [30]. Dead shrimps were removed immediately when they were found. All treatments were run in triplicate with similar conditions.

Median lethal concentrations $\left(\mathrm{LC}_{50}\right.$ ) with $95 \%$ confidence limits were calculated by Trimmed Spearman-Karber Method [31]. The standard error of the difference was used to determine statistical differences in $\mathrm{LC}_{50}$ values and the effect of salinity to the acute toxicity of beta-cypermethrin and Acephate at different exposure time was analyzed by the t-test.

\section{Results and Discussion}

Signs of toxicity in fish poisoned with beta-cypermethrin generally include the changes of loss equilibrium, color darkening and staying motionless [10]. Signs of toxicity in terrestrial animals poisoned with Acephate include muscular weakness, tremors, reduced activity [32], but reports on signs of toxicity in aquatic animals were limited. In this study, less toxic symptom can be observed for L. vannamei poisoned with both beta-cypermethrin and Acephate. Dying shrimp showed pronounced whiter body color compared with the alive, and the shrimp dying, when turned over, was nearly immobile on the bottom or showed little movement when touched with a glass stick.

The percentages of mortality recorded for each treatment are shown in Table 1. No mortality was observed in the controls at either salinity or in the treatments of $0.10 \mu \mathrm{g} / \mathrm{L}$ at $20.0 \%$ for beta-cypermethrin during the $96 \mathrm{~h}$. However, $100 \%$ mortality occurred in the treatments of 101.25 $\mathrm{mg} / \mathrm{L}$ at $5.0 \%$ and $151.88 \mathrm{mg} / \mathrm{L}$ at $20.0 \%$ for Acephate and $3.20 \mu \mathrm{g} / \mathrm{L}$ at $20.0 \%$ for beta-cypermethrin after $24 \mathrm{~h}$ of exposure. The mean $\mathrm{LC}_{50}$

\begin{tabular}{|c|c|c|c|c|c|c|c|c|c|c|}
\hline \multirow{2}{*}{\begin{tabular}{|l|} 
Salinity \\
$5 \%$ \\
\end{tabular}} & \multicolumn{5}{|c|}{ Beta-cypermethrin } & \multicolumn{5}{|c|}{ Acephate } \\
\hline & $\begin{array}{l}\text { Concentration } \\
(\mu \mathrm{g} / \mathrm{L})\end{array}$ & $24 \mathrm{~h}$ & $48 \mathrm{~h}$ & $72 \mathrm{~h}$ & $96 \mathrm{~h}$ & $\begin{array}{l}\text { Concentration } \\
\text { (mg/L) }\end{array}$ & $24 \mathrm{~h}$ & $48 \mathrm{~h}$ & $72 \mathrm{~h}$ & $72 \mathrm{~h}$ \\
\hline & 0.00 & $0.0 \pm 0.0$ & $0.0 \pm 0.0$ & $0.0 \pm 0.0$ & $0.0 \pm 0.0$ & 0.00 & $0.0 \pm 0.0$ & $0.0 \pm 0.0$ & $0.0 \pm 0.0$ & $0.0 \pm 0.0$ \\
\hline & 0.05 & $0.0 \pm 0.0$ & $10.0 \pm 0.0$ & $16.7 \pm 5.8$ & $20.0 \pm 0.0$ & 13.30 & $0.0 \pm 0.0$ & $6.7 \pm 5.8$ & $20.0 \pm 0.0$ & $26.7 \pm 5.8$ \\
\hline & 0.10 & $10.0 \pm 0.0$ & $16.7 \pm 5.8$ & $26.7 \pm 5.8$ & $30.0 \pm 0.0$ & 20.00 & $0.0 \pm 0.0$ & $20.0 \pm 0.0$ & $33.3 \pm 5.8$ & $60.0 \pm 0.0$ \\
\hline & 0.20 & $16.7 \pm 5.8$ & $26.7 \pm 5.8$ & $46.7 \pm 5.8$ & $56.7 \pm 5.8$ & 30.00 & $20.0 \pm 0.0$ & $36.7 \pm 5.8$ & $50.0 \pm 0.0$ & $76.7 \pm 5.8$ \\
\hline & 0.40 & $43.3 \pm 11.5$ & $56.7 \pm 5.8$ & $73.3 \pm 11.5$ & $76.7 \pm 5.8$ & 45.00 & $36.7 \pm 5.8$ & $56.7 \pm 5.8$ & $76.7 \pm 5.8$ & $100.0 \pm 0.0$ \\
\hline & 0.80 & $76.7 \pm 5.8$ & $86.7 \pm 5.8$ & $100.0 \pm 0.0$ & $100.0 \pm 0.0$ & 67.50 & $56.7 \pm 5.8$ & $80.0 \pm 10.0$ & $100.0 \pm 0.0$ & $100.0 \pm 0.0$ \\
\hline \multirow[t]{8}{*}{$20 \%$} & 1.60 & $96.7 \pm 5.8$ & $100.0 \pm 0.0$ & $100.0 \pm 0.0$ & $100.0 \pm 0.0$ & 101.25 & $100.0 \pm 0.0$ & $100.0 \pm 0.0$ & $100.0 \pm 0.0$ & $100.0 \pm 0.0$ \\
\hline & 0.00 & $0.0 \pm 0.0$ & $0.0 \pm 0.0$ & $0.0 \pm 0.0$ & $0.0 \pm 0.0$ & 0.00 & $0.0 \pm 0.0$ & $0.0 \pm 0.0$ & $0.0 \pm 0.0$ & $0.0 \pm 0.0$ \\
\hline & 0.10 & $0.0 \pm 0.0$ & $0.00 \pm 0.0$ & $0.00 \pm 0.0$ & $0.0 \pm 0.0$ & 20.00 & $0.0 \pm 0.0$ & $13.3 \pm 5.8$ & $23.3 \pm 5.8$ & $33.3 \pm 5.8$ \\
\hline & 0.20 & $6.7 \pm 5.8$ & $16.7 \pm 5.8$ & $23.3 \pm 5.8$ & $26.7 \pm 5.8$ & 30.00 & $0.0 \pm 0.0$ & $20.0 \pm 10.0$ & $40.0 \pm 10.0$ & $53.3 \pm 5.8$ \\
\hline & 0.40 & $23.3 \pm 5.8$ & $40.0 \pm 10.0$ & $43.3 \pm 5.8$ & $43.3 \pm 5.8$ & 45.00 & $36.7 \pm 5.8$ & $60.0 \pm 10.0$ & $73.3 \pm 5.8$ & $83.3 \pm 5.8$ \\
\hline & 0.80 & $43.3 \pm 5.8$ & $80.0 \pm 0.0$ & $83.3 \pm 5.8$ & $86.7 \pm 5.8$ & 67.50 & $63.3 \pm 5.8$ & $73.3 \pm 5.8$ & $100.0 \pm 0.0$ & $100.0 \pm 0.0$ \\
\hline & 1.60 & $83.3 \pm 5.8$ & $100.0 \pm 0.0$ & $100.0 \pm 0.0$ & $100.0 \pm 0.0$ & 101.25 & $80.0 \pm 10.0$ & $96.7 \pm 5.8$ & $100.0 \pm 0.0$ & $100.0 \pm 0.0$ \\
\hline & 3.20 & $100.0 \pm 0.0$ & $100.0 \pm 0.0$ & $100.0 \pm 0.0$ & $100.0 \pm 0.0$ & 151.88 & $100.0 \pm 0.0$ & $100.0 \pm 0.0$ & $100.0 \pm 0.0$ & $100.0 \pm 0.0$ \\
\hline
\end{tabular}

Table 1: The mortality recorded for each concentration tested and for both drug at both salinities.

Note: values are means \pm standard error (S. E.) of three replicates (\%)

\begin{tabular}{|c|c|c|c|c|c|}
\hline \multirow[t]{2}{*}{ Salinity } & \multirow[t]{2}{*}{ Replicate number } & \multicolumn{4}{|c|}{ LC $_{50}(95 \%$ confidence interval) } \\
\hline & & $24 \mathrm{~h}$ & $48 \mathrm{~h}$ & $72 \mathrm{~h}$ & $96 \mathrm{~h}$ \\
\hline \multirow[t]{4}{*}{$5 \%$} & \multicolumn{5}{|c|}{ beta-cypermethrin $(\mu \mathrm{g} / \mathrm{L})$} \\
\hline & 1 & $0.37(0.26-0.53)$ & $0.28(0.18-0.44)$ & $0.18(0.10-0.30)$ & $0.16(0.09-0.27)$ \\
\hline & 2 & $0.57(0.39-0.82)$ & $0.28(0.18-0.44)$ & $0.18(0.10-0.30)$ & $0.16(0.09-0.27)$ \\
\hline & 3 & $0.37(0.26-0.53)$ & $0.39(0.26-0.59)$ & $0.25(0.16-0.39)$ & $0.19(0.11-0.34)$ \\
\hline \multirow[t]{3}{*}{$20 \%$} & 1 & $0.80(0.54-1.14)$ & $0.49(0.37-0.66)$ & $0.43(0.31-0.60)$ & $0.43(0.31-0.60)$ \\
\hline & 2 & $0.80(0.56-1.14)$ & $0.43(031-0.60)$ & $0.40(0.29-0.54)$ & $0.37(0.27-0.52)$ \\
\hline & 3 & $0.70(0.50-0.96)$ & $0.40(0.29-0.56)$ & $0.32(0.26-0.53)$ & $0.35(0.25-0.48)$ \\
\hline \multirow[t]{4}{*}{$5 \%$} & \multicolumn{5}{|l|}{ Acephate (mg/L) } \\
\hline & 1 & $50.82(41.39-62.39)$ & $36.27(27.30-48.20)$ & $28.03(20.47-30.40)$ & $17.60(12.85-24.11)$ \\
\hline & 2 & $52.11(43.12-62.97)$ & $41.48(32.48-52.41)$ & $27.29(19.47-30.25)$ & $19.54(14.87-25.68)$ \\
\hline & 3 & $50.82(41.39-62.39)$ & $36.27(27.30-48.20)$ & $28.03(20.47-30.40)$ & $17.60(12.85-24.11)$ \\
\hline \multirow[t]{3}{*}{$20 \%$} & 1 & $62.21(50.93-75.97)$ & $40.15(31.90-50.53)$ & $32.10(25.20-40.80)$ & $24.49(15.71-30.19)$ \\
\hline & 2 & $62.24(50.30-77.02)$ & $41.35(29.35-58.40)$ & $34.64(23.00-52.17)$ & $28.52(20.76-30.18)$ \\
\hline & 3 & $55.11(45.65-66.54)$ & $48.97(39.40-60.86)$ & $35.92(27.63-46.70)$ & $29.00(20.62-40.80)$ \\
\hline
\end{tabular}

Table 2: $L_{5}$ values and $95 \%$ confidence intervals of beta-cypermethrin and acephate to $L$. vannamei juveniles in renewal acute toxicity test exposed from 24 to $96 \mathrm{~h}$. 
Citation: Wang X, Li E, Xiong Z, Chen K, Yu N (2013) Low Salinity Decreases the Tolerance to Two Pesticides, Beta-cypermethrin and Acephate, of White-leg Shrimp, Litopenaeus vannamei. J Aquac Res Development 4: 190 doi:10.4172/2155-9546.1000190

Page 3 of 5

values of beta-cypermethrin at $24,48,72$ and $96 \mathrm{~h}$ were $0.437,0.317$, $0.203,0.170 \mu \mathrm{g} / \mathrm{L}$ to the shrimp at $5.0 \%$, and were $0.767,0.440,0.383$, $0.383 \mu \mathrm{g} / \mathrm{L}$ at $20.0 \%$. While for Acephate, the mean $\mathrm{LC}_{50}$ values at 24 , 48,72 and $96 \mathrm{~h}$ were $51.250,38.007,27.783,18.247 \mathrm{mg} / \mathrm{L}$ at $5.0 \%$, and were $59.853,43.390$, and $34.220,27.337 \mathrm{mg} / \mathrm{L}$ at $20.0 \%$ (Figure 1 and Table 2). The results indicated that L. vannamei at low salinity is more sensitive to the ambient beta-cypermethrin and Acephate toxicity. Meanwhile, beta-cypermethrin had higher toxicity than Acephate to $L$. vananmei at either salinity.

The $\mathrm{LC}_{50}$ values for beta-cypermethrin and Acephate to aquatic animals reported in the existing literatures are shown in Table 3, which support the finding of higher toxicity of beta-cypermethrin to white shrimp in this study, though the $\mathrm{LC}_{50}$ values of both pesticides varied in different aquatic organisms. When compared with the toxicity of other pesticides reported to L. vannamei (Table 4), except for permethrin, beta-cypermethrin is more highly toxic to L. vannamei than some other commonly used pesticides, such as diazinon [25], propiconazole [25], parathion [26], pyazosulfuron-ethyl [27], chlordane [27], DDT [28], lorsban [28], and lindane [28]. While the toxicity of Acephate to $L$. vanname $i$ is less than that of other pesticides except for pyrazosulfuronethyl (Table 4). According to the determination of toxicity for different pesticides [33], beta-cypermethrin is extremely toxic to $L$. vannamei (96 $\mathrm{h} \mathrm{LC}_{50}<0.1 \mathrm{mg} / \mathrm{L}$ ), while Acephate is low toxic (96 h LC $\mathrm{L}_{50}$ is $10-100$ $\mathrm{mg} / \mathrm{L})$.

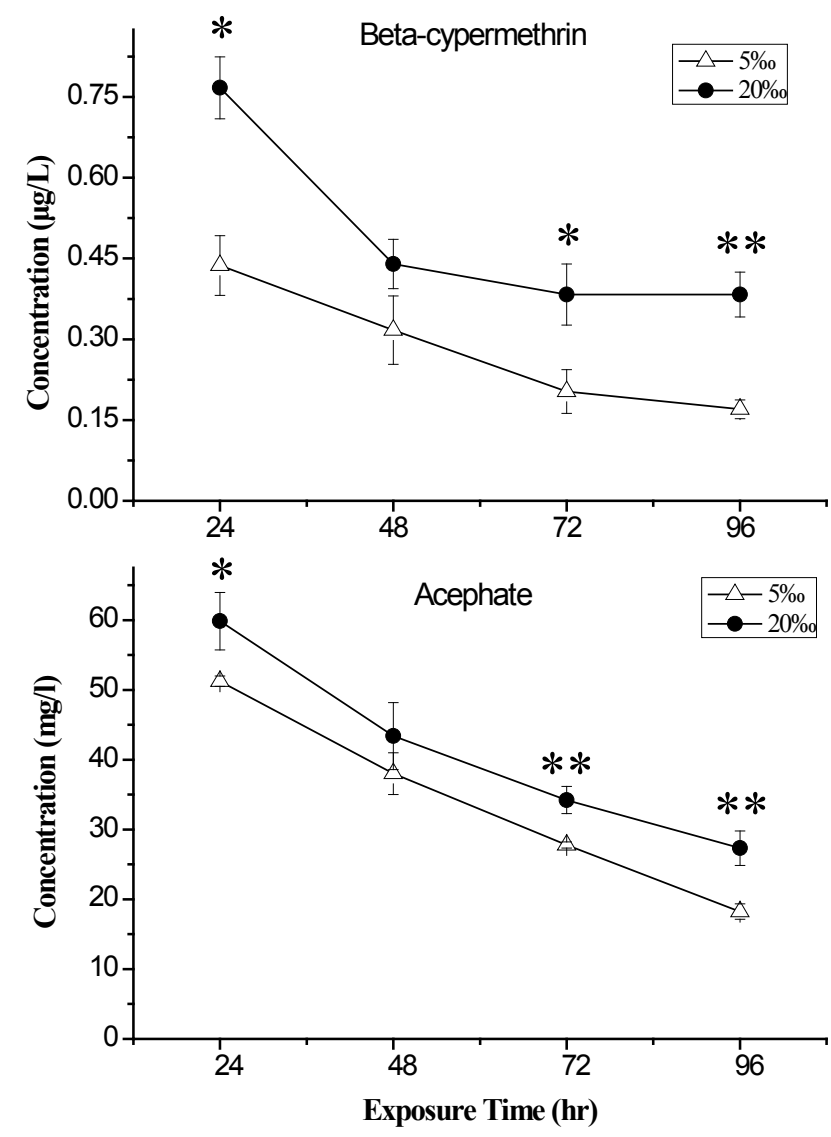

Figure 1: $L C_{50}$ values for beta-cypermethrin (upper) and acephate (down) to $L$. vannamei exposed from 24 to $96 \mathrm{~h}$ at $5 \%(\Delta)$ and $20.0 \%(\bullet)$. "*” and "**” mean $p<0.05$ and $p<0.01$ of t-test, respectively.

\begin{tabular}{|l|l|l|l|}
\hline Species & \multicolumn{2}{l|}{ Scientific name } & Source \\
\hline Beta-cypermethrin $(\mu \mathrm{g} / \mathrm{L})$ & \multicolumn{2}{l|}{ LC $_{50}$} & \\
\hline Common carp & Cyprinus carpio & $\begin{array}{l}2.6(96 \mathrm{~h}) \\
0.9-1.1(96 \mathrm{~h})\end{array}$ & $\begin{array}{l}{[11]} \\
{[9]}\end{array}$ \\
\hline Rainbow trout & Oncorhynchus mykiss & $8.2(96 \mathrm{~h})$ & {$[9]$} \\
\hline Brown trout & Salmo trutta & $1.2(96 \mathrm{~h})$ & {$[9]$} \\
\hline Atlantic salmon & Salmo salar & $2.0(96 \mathrm{~h})$ & {$[8]$} \\
\hline Guppy & Poecilia reticulata & $21.4(48 \mathrm{~h})$ & {$[10]$} \\
\hline Nile tilapia & Oreochromis niloticus & $21.4(24 \mathrm{~h})$ & {$[12]$} \\
\hline Mosquito fish & Gambusia affinis & $9.0(26 \mathrm{~h})$ & {$[8]$} \\
\hline Desert pupfish & Cyprinodon macularius & $10.0(24 \mathrm{~h})$ & {$[8]$} \\
\hline Acephate (mg/L) & & & \\
\hline Silver barb & Barbus choloensis & $530(96 \mathrm{~h})$ & {$[19]$} \\
\hline Mosquito fish & Gambusia affinis & $6000(96 \mathrm{~h})$ & {$[18]$} \\
\hline Bluegills & Lepomis macrochirus & $2050(96 \mathrm{~h})$ & {$[34]$} \\
\hline Opossum shrimp & Americamysis bahia & $7.3(96 \mathrm{~h})$ & {$[19]$} \\
\hline American lobster & Homarus americanus & $0.35(96 \mathrm{~h})$ & {$[19]$} \\
\hline Brown shrimp & Penaeus aztecus & $22.9(96 \mathrm{~h})$ & {$[18]$} \\
\hline Northern pink shrimp & Penaeus duorarum & $3.8(96 \mathrm{~h})$ & {$[19]$} \\
\hline & & & \\
\hline
\end{tabular}

Table 3: $L C_{50}$ values for aquatic animals reported in the existing literature.

\begin{tabular}{|l|l|l|l|}
\hline Pesticides & LC $_{50}$ & Size/Stage & Source \\
\hline Diazinon & $0.226 \mathrm{mg} / \mathrm{L}-96 \mathrm{~h}$ & Postlarvae & {$[25]$} \\
\hline Propiconazole & $3.635 \mathrm{mg} / \mathrm{L}-96 \mathrm{~h}$ & Postlarvae & {$[25]$} \\
\hline Parathion & $8.6 \mathrm{mg} / \mathrm{L}-24 \mathrm{~h}$ & Nauplius & {$[26]$} \\
\hline & $8.2 \mathrm{mg} / \mathrm{L}-24 \mathrm{~h}$ & Zoaea & {$[26]$} \\
\hline & $8.0 \mathrm{mg} / \mathrm{L}-24 \mathrm{~h}$ & Mysis & {$[26]$} \\
\hline & $0.002 \mathrm{mg} / \mathrm{L}-24 \mathrm{~h}$ & Nauplius & {$[26]$} \\
\hline Pyrazosulfuron-ethyl & $>1000 \mathrm{mg} / \mathrm{L}-96 \mathrm{~h}$ & $5 \mathrm{~g}$ & {$[27]$} \\
\hline Permethrin & $0.00000933 \mathrm{mg} / \mathrm{L}-96 \mathrm{~h}$ & $5 \mathrm{~g}$ & {$[27]$} \\
\hline Chlordane & $0.0632 \mathrm{mg} / \mathrm{L}-48 \mathrm{~h}$ & $2.44 \mathrm{~g}$ & {$[28]$} \\
\hline DDT & $0.0087 \mathrm{mg} / \mathrm{L}-48 \mathrm{~h}$ & $2.84 \mathrm{~g}$ & {$[28]$} \\
\hline Lorsban & $0.0048 \mathrm{mg} / \mathrm{L}-48 \mathrm{~h}$ & $2.49 \mathrm{~g}$ & {$[28]$} \\
\hline Lindance & $0.0039 \mathrm{mg} / \mathrm{L}-48 \mathrm{~h}$ & $2.76 \mathrm{~g}$ & {$[28]$} \\
\hline
\end{tabular}

Table 4: $L_{50}$ values for some pesticides to $L$. vannamei reported in the existing literature.

Besides, the $96 \mathrm{~h} \mathrm{LC}_{50}$ values of beta-cypermethrin to L. vannamei at either $5.0 \%$ or $20.0 \%$ in this study were much lower than the $\mathrm{LC}_{50}$ values reported in fishes (Table 3), such as Cyprinus carpio $[9,11]$, Oncorhynchus mykiss [9], Salmo trutta [9], Salmo salar [8], Poecilia reticulata [10], Gambusia affinis [8], Cyprinodon macularius [8]. For Acephate, the toxicity to L. vannamei at either salinity and to other crustacean species, including A. bahia [19], H. americanus [19], $P$. aztecus [18], and P. duorarum [19] were also much lower than the values reported in fishes $[18,19,34]$. The susceptibility of crustacean species to these pesticides are due to the relatively undeveloped detoxification system which cannot degrade most toxic compounds efficiently [35], and the open vascular system of crustacean species make ambient toxicants enter their body easily.

L. vannamei is more susceptible to ambient beta-cypermethrin and Acephate at $5.0 \%$ than at $20.0 \%$, and significant differences were both found at $24 \mathrm{~h}, 72 \mathrm{~h}$ and $96 \mathrm{~h}(\mathrm{P}<0.05)$. Similar findings were reported in the toxic effects of ambient ammonia, boron and nickel to $L$. vannamei. The $96 \mathrm{~h} \mathrm{LC}_{50}$ with $95 \%$ confidence limit of L. vannamei at $3.0 \%$ to ambient ammonia-N was $9.33 \mathrm{mg} / \mathrm{L}$ [36], which was significantly lower than the previous results [37], which reported that the $\mathrm{LC}_{50}$ of ammonia to L. vannamei at 15 and $25 \%$ were 24.39 and $35.40 \mathrm{mg} / \mathrm{L}$ respectively. The mean $\mathrm{LC}_{50}$ values of boron at $24 \mathrm{~h}, 48 \mathrm{~h}, 72 \mathrm{~h}$ and $96 \mathrm{~h}$ were 552.55, $153.35,50.14,25.05 \mathrm{mg} / \mathrm{L}$ to the shrimp at $3.0 \%$, and were 598.13 , 
Citation: Wang X, Li E, Xiong Z, Chen K, Yu N (2013) Low Salinity Decreases the Tolerance to Two Pesticides, Beta-cypermethrin and Acephate, of White-leg Shrimp, Litopenaeus vannamei. J Aquac Res Development 4: 190 doi:10.4172/2155-9546.1000190

$219.52,147.8,80.06 \mathrm{mg} / \mathrm{L}$ at $20.0 \%$ [38]. The $96 \mathrm{~h} \mathrm{LC}_{50}$ values were 41 $\mu \mathrm{mol} / \mathrm{L}$ and $362 \mu \mathrm{mol} / \mathrm{L}$ for L. vannamei at $5 \%$ and $25 \%$, respectively [39] many previous studies have demonstrated that the optimal salinity for growth of $L$. vannamei should be around $20 \%[36,40]$. When $L$. vannamei is exposed to dilute medium or low salinity, many problems such as the passive loss of $\mathrm{Na}^{+}$and $\mathrm{Cl}^{-}$will occur [41], and though $L$. vannamei could cope with these problems in different physiological ways [42], extremely low salinity is still a serious stress for L. vannamei. Therefore, lower mean $\mathrm{LC}_{50}$ values of beta-cypermethrin and Acephate to white shrimp were observed at $5.0 \%$ when compared with those at $20.0 \%$ in the present study.

Overall, ambient beta-cypermethrin and Acephate can pose an acute toxic effect on L. vannamei. Beta-cypermethrin is extremely toxic to L. vannamei, while Acephate is low toxic. L. vannamei at low salinity was more sensitive to the toxicity of these two toxicants.

\section{Acknowledgement}

This project was supported by grants from National Natural Science Foundation of China (No. 31172422; 31001098), Special Fund for Agro-scientific Research in the Public Interest (No. 201003020, 201203065), National Key Technology Support Program (2012BAD25B03), Shanghai Committee of Science and Technology (No. 09ZR1409800; 10JC1404100), Specialized Research Fund for the Doctoral Program of Higher Education of China (No. 20100076120006), Shanghai Agriculture Science and Technology Key Grant (No.2-1, 2009), Shanghai technology system for Chinese mitten-handed crab industry, Shanghai University Knowledge Service Platform Shanghai Ocean University aquatic animal breeding center (ZF1206), and partly by the E-Institute of Shanghai Municipal Education Commission (No. E03009) and ECNU innovation fund. We also thank Qiu Yong from Hainan University for his help during the experiment.

\section{Competing Interests}

The authors declare that they have no competing interests.

\section{Authors' Contributions}

Conceived and designed the experiments: EL LC, NY. Performed the experiments: XW, ZX, EL, KC. Analyzed the data: ZX, XD, EL. Wrote the paper: $X W$, EL, ZD, LC. All authors read and approved the final manuscript.

\section{References}

1. Widenfalk A (2002) Pesticide Bioavailability in Aquatic Sediments-A Literature Review. Department of Environment Assessment, Swedish University of Agricultural Sciences.

2. Helfrich LA, Weigmann DL, Hipkins P, Stinson ER (1996) Pesticides and Aquatic Animals: A Guide to Reducing Impacts on Aquatic Systems. Virginia State University, Virginia.

3. Kumar A, Correll R, Grocke S, Bajet C (2010) Toxicity of selected pesticides to freshwater shrimp, Paratya australiensis (Decapoda: Atyidae): use of time series acute toxicity data to predict chronic lethality. Ecotox Environ Safe 73: 360-369.

4. Abdullah AR, Kumar A, Chapman JC (1994) Inhibition of acetylcholinesterase in the Australian freshwater shrimp (Paratya australiensis) by profenofos. Environmental Toxicology and Chemistry 13: 1861-1866.

5. Olima C, Pablo F, Lim RP (1997) Comparative tolerance of three populations of the freshwater shrimp (Paratya australiensis) to the organophosphate pesticide, chlorpyrifos. Bull Environ Contam Toxicol 59: 321-328.

6. Phyu YL, Warne MS, Lim RP (2004) Toxicity of atrazine and molinate to the cladoceran Daphnia carinata and the effect of river water and bottom sediment on their bioavailability. Arch Environ Contam Toxicol 46: 308-315.

7. Phyu YL, Warne MS, Lim RP (2005) Toxicity and bioavailability of atrazine and molinate to the freshwater shrimp (Paratya australiensis) under laboratory and simulated field conditions. Ecotoxicol Environ Safe 60: 113-122.

8. Smith TM, Stratton GW (1986) Effects of synthetic pyrethroid insecticides on nontarget organisms. Residue Reviews 97: 93-120.

9. Bradbury SP, Coats JR (1989) Comparative toxicology of the pyrethroid insecticides. Rev Environ Contam Toxicol 108: 133-177.
10. Polat H, Erkoc FU, Viran R, Kocak O (2002) Investigation of acute toxicity of beta-cypermethrin on guppies Poecilia reticulate. Chemosphere 49: 39-44

11. Saha S, Kaviraj A (2008) Acute toxicity of synthetic pyrethroid cypermethrin to some freshwater organisms. Bull Environ Contam Toxicol 80: 49-52.

12. Benli ACK, Selvi M, Sepici-Dincel A, Sarikaya R, Yildirim MZ, et al. (2009) Acute toxicity of beta-cypermethrin on Nile tilapia (Oreochromis Niloticus L) fingerlings. Journal of Environmental Protection and Ecology 10: 104-109.

13. Kidd H, James DR (1991) The Agrochemicals Handbook Royal Society of Chemistry Information Services, Cambridge, UK

14. ZinkI JGP, Shea J, Nakamoto RJ, Callman J (1987) Effects on cholinesterases of rainbow trout exposed to acephate and methamidophos. Bull Environ Contam Toxicol 38: 22-28.

15. Jena GB, Bhunya SP (1994) Mutagenicity of an organophosphate insecticide acephate-an in vivo study in chicks. Mutagenesis 9: 319-324.

16. Carver JH, Bootman J, Cimino MC, Esber HJ, Kirby P, et al. (1985) Genotoxic potential of acephate technical: in vitro and in vivo effects. Toxicology 35: 125142.

17. Perocco P, DelCiello C, Colacci A, Pozzetti L, Paolini M, et al. (1996) Cytotoxic activity and transformation of BALB/c 3 T3 cells in vitro by the insecticide acephate. Cancer Lett 106: 147-153.

18. PED (2000) Pesticide Ecotoxicity Database Office of Pesticide Programs, Environmental Fate and Effects Division, US EPA, Washington, DC.

19. USEPA (2007) ECOTOX User Guide: ECOTOXicology Database System Version 4.0

20. Pante MJR (1990) Influence of environmental stress on the heritability of molting frequency and growth rate of the penaeid shrimp, Penaeus vannamei. University of Houston, USA.

21. Frias-Espericueta MG, Voltolina D, Osuna-Lopez JI (2001) Acute toxicity of cadmium, mercury, and lead to whiteleg shrimp (Litopenaeus vannamei) postlarvae. Bull Environ Contam Toxicol 67: 580-586.

22. McGraw WJ, Davis DA, Teichert-Coddington D, Rouse DB (2002) Acclimation of Litopenaeus vannamei postlarvae to low salinity: Influence of age, salinity endpoint, and rate of salinity reduction. Journal of the World Aquaculture Society 33: 78-84

23. Saoud IP, Davis DA, Rouse DB (2003) Suitability studies of inland well waters for Litopenaeus vannamei culture. Aquaculture 217: 373-383.

24. Cheng KM, Hu CQ, Liu YN, Zheng SX, Qi XJ (2006) Effects of dietary calcium, phosphorus and calcium/phosphorus ratio on the growth and tissue mineralization of Litopenaeus vannamei reared in low-salinity water Aquaculture 251: 472-483.

25. Shamoushaki MMN (2012) Acute toxicity of insecticide, Diazinon and fungicide, Tilt (Propiconazole) on Pacific white Shrimp, Litopenaeus vannamei postlarvae and Palaemon adspersus juveniles. Journal of Research in Biology 2: 160-166.

26. Ru S, Li Y, Jiang M (1998) Sensitivity of prawn to organophosphorus pesticides at its different development stages. Chinese Journal of Applied Ecology 9: 305308

27. Mello GLD, Júnior HA, Garcia S, Vinatea L (2011) Acute toxicity of pyrazosulfuron-ethyl and permethrin to juvenile Litopenaeus vannamei. Acta Scientiarum : Biological Sciences 33: 1-6.

28. Reyes JGG, Jasso AM, Lizarraga CV (1996) Toxic effects of organochlorine pesticides on Penaeus vannamei Shrimps in Sinaloa, Mexico. Chemosphere 33: $567-575$

29. Brecken-Folse JA, Mayer FL, Pedigo LE, Marking LL (1994) Acute toxicity of 4-nitrophenol, 2,4-dinitrophenol, terbufos and trichlorfon to grass shrimp (Palaemonetes spp) and sheepshead minnows (Cyprinodon variegatus) as affected by salinity and temperature. Environmental Toxicology and Chemistry 13: $67-77$.

30. Lin YC, Chen JC (2003) Acute toxicity of nitrite on Litopenaeus vanname (Boone) juveniles at different salinity levels. Aquaculture 224: 193-201.

31. Hamilton MA, Russo RC, Thurston RV (1977) Trimmed Spearman-Karber method for estimating median lethal concentrations in toxicity bioassays. Environ Sci Technol 11: 714-719.

32. WHO (2005) Pesticide residues in food-2005: Acephate; International 
Citation: Wang X, Li E, Xiong Z, Chen K, Yu N (2013) Low Salinity Decreases the Tolerance to Two Pesticides, Beta-cypermethrin and Acephate, of White-leg Shrimp, Litopenaeus vannamei. J Aquac Res Development 4: 190 doi:10.4172/2155-9546.1000190

Page 5 of 5

programmed on Chemical Safety. World Health Organization, Geneva, Switzerland, 3-16 pp.

33. Shamoushaki MMN, Soltani M, Kamali A, Imanpoor MR, Sharifpour I, et al (2012) Effects of organophosphate, diazinon on some haematological and biochemical changes in Rutilus frisii kutum (Kamensky, 1901) male brood stocks. Iranian Journal of Fisheries Sciences 11: 105-117.

34. Spencer EY (1981) Guide to the Chemicals Used in Crop Protection. Agriculture, Canada.

35. Sanchez-Bayo FP (2012) Insecticides mode of action in relation to their toxicity to non-target organisms. J Anal Toxicol.

36. Li E, Chen L, Zeng C, Chen X, Yu N, et al. (2007) Growth, body composition, respiration and ambient ammonia nitrogen tolerance of the juvenile white shrimp, Litopenaeus vannamei, at different salinities. Aquaculture 265: 385390

37. Lin YC, Chen JC (2001) Acute toxicity of ammonia on Litopenaeus vannamei Boone juveniles at different salinity levels. J Exp Mar Biol Ecol 259: 109-119.
38. Li E, Xiong Z, Chen L, Zeng C, Li K (2008) Acute toxicity of boron to juvenile white shrimp, Litopenaeus vannamei, at two salinities. Aquaculture 278: 175178.

39. Leonard EM, Barcarolli I, Silva KR, Wasielesky W, Wood CM, et al. (2011) The effects of salinity on acute and chronic nickel toxicity and bioaccumulation in two euryhaline crustaceans: Litopenaeus vannamei and Excirolana armata. Comp Biochem Physiol C 154: 409-419.

40. Huang HJ (1983) Factors affecting the successful culture of Penaeus stylirostris and Penaeus vannamei at an estuarine power plant site: temperature, salinity, inherent growth variability, damselfly nymphpredation, population density and distribution, and polyculture. Texas A\&M University, Houston.

41. Palacios E, Bonilla A, Luna D, Racotta IS (2004) Survival, Na+/K+-ATPase and lipid responses to salinity challenge in fed and starved white pacific shrimp (Litopenaeus vannamei) postlarvae. Aquaculture 234: 497-511.

42. Li E, Chen L, Zeng C, Yu N, Xiong Z, et al. (2008) Comparison of digestive and antioxidant enzymes activities, haemolymph oxyhemocyanin contents and hepatopancreas histology of white shrimp, Litopenaeus vannamei, at various salinities. Aquaculture 274: 80-86. 